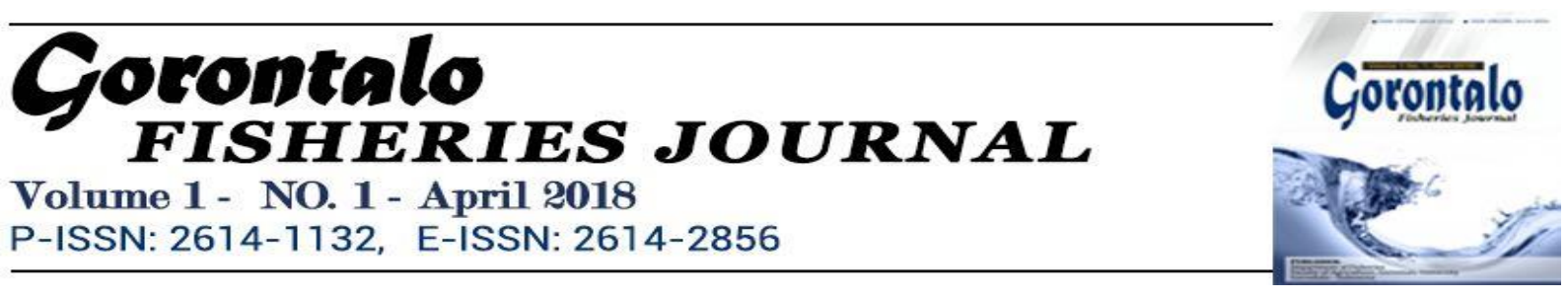

\title{
Pengaruh Penambahan Madu Pada Proses Pengenceran Sperma Terhadap Daya Tetas Telur Ikan Lele (Clarias sp)
}

\section{Meriyanti Ngabito ${ }^{1}$ dan Sartika R. Rahim ${ }^{2}$}

1 Mahasiswa Program Studi Perikanan dan Kelautan Universitas Gorontalo

E-mail : meriyantingabito86@gmail.com

2 Staf Pengajar Program Studi Perikanan dan Kelautan Universitas Gorontalo

\begin{abstract}
The objective of this study was to evaluate the influence of honey addition on sperm dillution process to eggs hatchability of catfish (Clarias sp.) in Gorontalo Fish Seed Centre. This study has been using completely randomized design with 4 threatments and 3 replications each of them. Treatment A: $0 \mathrm{ml} ; \mathrm{B:}: 0.70 \mathrm{ml}$; $: 0.75 \mathrm{ml}$; and $\mathrm{D}: 80 \mathrm{ml}$ each of them was in $100 \mathrm{ml} ; 99.30 \mathrm{ml} ; 99.25 \mathrm{ml}$ and $99.20 \mathrm{ml}$ solution of $\mathrm{NaCl}$. The results of this study showed that the highest of larvae survival was on treatment $D(76,67 \%)$, followed by treatment $C$ $(71,11 \%)$ and $B(65,56 \%)$, while the lowest was treatment $A(61,11 \%)$. The parameter of water quality which is measured were DO was 3,8 ppm, the temperature was $24,5^{\circ} \mathrm{C}$ and $\mathrm{pH}$ was 6,67. So it can be concluded that honey supplementation in sperm dilution has affect to the eggs hatchability and the growth of catfish larvae (Clarias sp).
\end{abstract}

Keywords : Addition of Honey, Sperm Dilution, Hatching Egg, Catfish (Clarias $s p$ ) 


\section{Pendahuluan}

Perkembangan perikanan Indonesia khususnya di sektor budidaya dewasa ini semakin meningkat. Salah satu yang potensial untuk dibudidayakan adalah ikan lele (Clarias sp.). Ikan ini sangat popular dan sudah dibudidayakan secara komersial terutama bagi masyarakat yang berada di Pulau Jawa. Produksi budidaya ikan lele terus meningkat, dilihat dari segi pasar, pemasarannya relatif mudah, banyak disukai oleh masyarakat karena selain dagingnya yang empuk, hampir tidak memiliki tulang, tidak memiliki duri, juga mengandung protein, vitamin dan asam lemak yang dibutuhkan tubuh serta yang juga tidak kalah penting adalah dijual dengan harga murah. Dari segi budidaya, ikan ini cukup mudah dibudidayakan, tidak memerlukan banyak biaya dan tidak memerlukan waktu yang lama untuk dipanen.

Ikan lele tidak hanya dipasarkan di dalam negeri melainkan juga telah merambah sampai ke manca negara seperti Taiwan, Singapura, Hongkong, Jepang, Belanda, Perancis, Italia, Spanyol, USA, Turki, Emirat Arab dan Afrika Selatan. Ikan ini telah diekspor dalam bentuk daging sayat (fillet), utuh (whole around), tanpa kepala (head less), tanpa insang dan isi perut (whole gill gutet) dan daging halus (surimi). Untuk memenuhi pasokan pasar baik dalam maupun luar negeri membuat para pembudidaya juga harus memikirkan cara agar ikan ini selalu tersedia. Salah satu cara yang dapat diupayakan adalah dengan melakukan pemijahan buatan dengan menggunakan hormon agar bisa menghasilkan larva dan benih dalam jumlah yang banyak. Akan tetapi, kendala yang sering dihadapi dalam pemijahan buatan seperti yang dikemukakan oleh Masrizal dan Efrizal (1997) adalah masih rendahnya fertilisasi sperma yang mengakibatkan rendahnya daya tetas telur. Selain itu, menurut Isnaini dan Suradi (2000), kurangnya ketersediaan cairan spermatozoa pada waktu pembuahan buatan serta aktivitas sperma yang relatif singkat. Konsentrasi sperma yang tinggi dapat menghambat aktivitas spermatozoa, karena berkurangnya daya gerak sehingga spermatozoa sukar menemukan atau menembus mikrofil sel telur yang mengakibatkan rendahnya fertilisasi sperma karena motilitas spermatozoa akan terus menurun setelah dikeluarkan dari tubuh ikan, sehingga menurutnya salah satu cara untuk mengatasi hal ini adalah menggunakan larutan pengencer yang dapat mempertahankan kehidupan spermatozoa. Bahan yang sering digunakan dalam pengenceran sperma adalah larutan $\mathrm{NaCl}$, larutan ini memberi sifat buffer, mempertahankan $\mathrm{pH}$ dalam suhu kamar, bersifat isotonis dengan cairan sel, melindungi spermatozoa terhadap penyeimbangan elektron yang sesuai. Namun penyimpanan spermatozoa dengan larutan ini hanya bisa digunakan tidak lebih dari 60 menit setelah penampungan karena kurang mengandung sumber energi yang dibutuhkan oleh spermatozoa.

Penambahan madu dalam pengenceran sperma ikan merupakan salah satu cara yang digunakan untuk memperoleh benih ikan, karena monosakarida yang dibutuhkan oleh spermatozoa terkandung dalam madu. Berdasarkan data United States Department of Agricultur (USDA) yang dikemukakan oleh 
Rahardianto et al, (2012), madu mengandung 38\% fruktosa; 31\% glukosa; $17,1 \%$ air; $7,2 \%$ maltose, $4,2 \%$ trisakarida dan beberapa poliskarida, $1.5 \%$ sukrosa; 0,5\% mineral, vitamin dan enzim. Madu dalam pengencer $\mathrm{NaCl}$ fisiologis diharapkan dapat mendukung daya hidup dan pergerakan spermatozoa sebagai sumber energi yang akan mempengaruhi daya tetas telur.

Berdasarkan uraian latar belakang di atas, penelitian ini bertujuan untuk mengetahui daya tetas telur ikan lele (Clarias $\mathrm{sp}$ ) yang diberi madu dengan larutan $\mathrm{NaCl}$ fisiologis pada proses pengenceran sperma. Hasil penelitian ini diharapkan dapat memberikan sedikit manfaat berupa informasi kepada pembudidaya ikan air tawar khususnya ikan lele serta sebagai bahan pertimbangan bagi para peneliti bahkan pemerintah.

\section{Metode Penelitian}

\subsection{Waktu dan Tempat}

Penelitian ini dilaksanakan selama 4 bulan dimulai pada bulan Januari sampai dengan bulan April 2015, di Balai Benih Ikan Enterpreneur Kota Gorontalo.

\subsection{Alat dan Bahan}

Alat yang digunakan selama penelitian diantaranya: timbangan digital, disposable ukuran $1 \mathrm{ml}$ tanpa jarum, sendok plastik, baskom, bulu ayam, loyang, ayakan, aerator, selang, batu aerasi, kain basah, gunting/cutter, termometer, DO Meter, pH meter. Bahan yang digunakan selama penelitian diantaranya induk jantan matang gonad dengan berat $1 \mathrm{~kg}$ yang berumur 12 bulan, induk betina matang gonad dengan berat 1,5 kg yang berumur 15 bulan, $\mathrm{NaCl}$, madu dan hormon Ovaprim.

\subsection{Metode Pengambilan Data}

Jenis data yang digunakan selama penelitian ini terdiri dari data primer dan data sekunder. Data primer diperoleh dari data hasil pengamatan daya tetas telur ikan lele (Clarias sp) dengan penambahan madu dalam pengenceran sperma serta dilengkapi oleh data pendukung berupa data deskriptif lingkungan dan parameter kualitas air. Data sekunder diperoleh dari literatur maupun bahan pendukung lainnya.

\subsection{Tahapan Penelitian}

Tahapan penelitian meliputi persiapan alat dan bahan, diantaranya: 1 . Persiapan dan Seleksi Induk, ikan yang digunakan dalam penelitian ini adalah ikan lele (Clarias sp) dengan bobot 1000-1500 gr/ekor sebanyak 4 ekor jantan dan 4 ekor betina, induk yang akan digunakan adalah induk yang telah matang gonad; 2. Persiapan Wadah dan Pemasangan Sistem Aerasi, Wadah penelitian 
yang digunakan pada proses penetasan telur adalah loyang plastik transparan yang berukuran panjang $25 \mathrm{~cm}$ x $25 \mathrm{~cm} 12$ unit, Selanjutnya dipasangkan batu aerasi sebanyak 12 titik pada setiap wadah; 3. Pengisisan Air, air yang digunakan terlebih dahulu disaring kemudian diendapkan pada loyang plastik yang sudah diisi batu aerasi, pengisian air sebanyak 3 liter air dengan ketinggian $15-18 \mathrm{~cm}$; 4. Penyuntikan Hormon Ovaprim, hormon ovaprim yang digunakan adalah syndel ovaprim, penyuntikan dilakukan dengan cara menutupi bagian mata induk ikan lele tujuannya agar induk lele tenang saat penyuntikan hormon, hormon bekerja sekitar 7-8 jam; 5). Pembuatan Larutan Pengencer Sperma, larutan pengencer sperma dibuat dengan menggunakan madu lebah hutan yang dilarutkan dalam $\mathrm{NaCl}$ Fisiologis pada loyang plastik. Variasi larutan pengencer madu yaitu dari $0 \mathrm{ml} ; 0,70 \mathrm{ml} ; 0,75 \mathrm{ml} ; 0,80 \mathrm{ml}$ dan $\mathrm{NaCl}$ fisiologis yaitu dari $100 \mathrm{ml}$; 99,30 ml; 99,25; 99,20 ml, masing-masing larutan perlakuan dihomogenkan menggunakan aerator 15 menit. Variasi larutan pengencer madu dari $0 \mathrm{ml} ; 0,60 \mathrm{ml} ; 0,65 \mathrm{ml}$ dan $0,70 \mathrm{ml}$ telah di uji coba kepada ikan nila (Oreochromis niloticus) oleh Yunus Ayer dan Joppy Mudeng, pada tahun 2015; 6. Proses Pengenceran Sperma Induk Lele Jantan, induk lele jantan yang sudah disuntik horman ovaprim selama 7-8 jam dibedah perutnya sampai ke anus kemudian kantung sperma diambil dan diberisihkan mengunakan larutan $\mathrm{NaCl}$ fisiologis agar kantung sperma terhindar dari bakteri/steril. Kemudian kantung sperma diencerkan dengan cara dipotongpotong kecil menggunakan gunting, cairan sperma yang ada di dalam kantung sperma ditampung dalam loyang plastik dan dicampurkan larutan pengencer sperma, setelah itu induk lele betina yang sudah disuntik dipijat/stripping perutnya, telur-telur hasil striping ditampung di loyang plastik. Cairan sperma yang sudah tercampur laruran pengencer sperma dimasukkan ke dalam loyang yang sudah berisi telur dan diaduk menggunakan bulu ayam sekitar 1 - 2 menit. Setelah tercampur rata dengan telur kemudian larutan pengencer dibuang sehingga tersisa telur saja, kemudian dimasukkan ke dalam wadah yang sudah terisi air untuk mengaktifkan sperma hingga terjadi penetasan telur, proses penetasannya 17 jam; 7). Penebaran Telur Lele, telur yang ditebar dihitung dengan cara manual, telur yang digunakan dalam setiap wadah penelitan sebanyak 30 butir telur dengan 3 liter air/wadah. Sehingga telur yang ditebar dalam 12 wadah penelitian sebanyak 360 butir telur lele; 8). Perhitungan Telur Ikan Lele, telur ikan lele yang sudah menetas / larva dihitung secara manual yaitu dihitung satu per satu dengan cara menggunakan sendok makan sampai larva yang ada di dalam wadah penelitian habis.

\subsection{Rancangan Penelitian}

Rancangan yang digunakan pada penelitian ini adalah model eksperimental dengan menggunakan analisis Rancangan Acak Lengkap (RAL). Penelitian terdiri dari 4 perlakuan dengan 3 kali ulangan sehingga diperoleh 12 satuan percobaan, yang masing-masing komposisi perlakuan adalah sebagai berikut: perlakuan A (0 ml madu dalam $100 \mathrm{ml} \mathrm{NaCl}$ Fisiologis), perlakuan B 
(0,70 $\mathrm{ml}$ madu dalam 99,30 $\mathrm{ml} \mathrm{NaCl}$ Fisiologis), perlakuan $\mathrm{C}(0,75 \mathrm{ml}$ madu dalam 99,25 $\mathrm{ml} \mathrm{NaCl}$ Fisiologis) dan perlakuan $\mathrm{D}$ (0,80 ml madu dalam 99,20 $\mathrm{ml} \mathrm{NaCl}$ Fisiologis).

\subsection{Analisis Data}

Data dianalisis secara statistik menggunakan analisis ragam (ANOVA) Rancangan Acak Lengkap. Kemudian dilanjutkan dengan uji BNT 5\% dan Uji BNT 1\%. Rumus yang digunakan mengikuti rumus yang digunakan oleh Gusrina (2008) sebagai berikut:

\section{Keterangan :}

$$
H P=\frac{N}{P} \times 100 \%
$$

Hp : Hatching percentage

$\mathrm{N}$ : Jumlah telur menetas

$\mathrm{P}:$ Jumlah telur yang ditebar

\subsection{Parameter Kualitas Air Yang Diukur}

\section{Suhu}

Alat pengukur suhu menggunakan termometer yang berasal dari lokasi penelitian dengan mencelupkannya ke dalam wadah penelitian dengan penentuan suhu berkisar 24-28 derajat celcius yang sudah diterapkan oleh (Muktiani, 2011). Pengukuran suhu dilakukan 1 hari sebanyak 3 kali.

\section{2. $\mathbf{p H}$}

Pengukuran $\mathrm{pH}$ menggunakan $\mathrm{pH}$ meter yang berasal dari lokasi penelitian dengan mencelupkannya ke dalam wadah penelitian. Pengukuran pH dilakukan 1 hari sebanyak 3 kali.

\section{Oksigen Terlarut / Dissolved oxygen (DO)}

Pengukuran DO atau oksigen terlarut menggunakan Oksimeter atau DO meter dengan cara dicelupkan ke dalam wadah penelitian, pengukuran DO dilakukan 1 hari sebanyak 3 kali.

\section{Hasil Dan Pembahasan}

\subsection{Daya Tetas Telur (Hatching Percentage) Ikan Lele}

Hasil penelitian perendaman sperma dengan madu terhadap daya tetas telur ikan lele (Clarias sp), dapat dilihat pada tabel 1. Perhitungan nilai ratarata keberhasilan penetasan telur yakni dengan merata-ratakan hatching 
percentage dari seluruh ulangan di setiap perlakuan. Berdasarkan hasil penelitian, diketahui bahwa perlakuan $\mathrm{D}$ dengan konsentrasi $0,80 \mathrm{ml}$ madu lebih efektif untuk memperpanjang dan menjaga kelangsungan hidup sperma serta dapat memberikan energi terhadap sperma ikan lele (Clarias sp). Hal ini terbukti dengan rata-rata keberhasilan penetasan telur ikan yang lebih tinggi $(76,67 \%)$ dan telur menetas selama 17 jam.

Tabel 1. Rata-Rata Keberhasilan Penetasan Telur Ikan Lele (Clarias sp) dengan Perbedaan Perendaman Madu

\begin{tabular}{cc}
\hline Perlakuan & $\begin{array}{r}\text { Rata-Rata Keberhasilan } \\
\text { Penetasan (\%) }\end{array}$ \\
\hline P A & 61,11 \\
P B & 65,56 \\
P C & 71,11 \\
P D & 76,67 \\
\hline
\end{tabular}

sehingga proses perkembangan embrio dari fase pembelahan sel (morula) sampai pembentukan organ (organogenesis) berjalan dengan baik. Kadar pH pada konsentrasi perlakuan $\mathrm{D} 0,80 \mathrm{ml}$ madu yaitu 6,67 berbeda sangat nyata dengan perlakuan $\mathrm{C}$ konsentrasi $0,75 \mathrm{ml}$ madu, perlakuan $\mathrm{B}$ 0,70 ml madu dan perlakuan A tanpa madu. Sedangkan perlakuan C dengan konsentrasi 0,75 ml madu menunjukkan perbedaan nyata terhadap perlakuan B dengan konsentrasi $0,70 \mathrm{ml}$ madu. Serta perlakuan B 0,70 $\mathrm{ml}$ madu menunjukkan perbedaan nyata terhadap perlakuan A dengan konsentrasi tanpa madu, kemudian menurun pada perendaman dengan konsentrasi 0,75 ml madu perlakuan $\mathrm{C}$ yaitu sebesar (71,11\%). Konsentrasi perlakuan $\mathrm{C} 0,75 \mathrm{ml}$ madu dengan menggunakan madu memberikan tingkat kehidupan terhadap telur $71,11 \%$. Rasio penetasan perlakuan $\mathrm{C}$ yang $71,11 \%$ ini tidak terlalu banyak terhadap penetasan.

Hal ini karena pemberian konsentrasi perlakuan $\mathrm{C} 0,75 \mathrm{ml}$ madu terlalu sedikit. Sehingga peranan madu yang terkandung dalam air tidak terlalu memberikan energi yang lebih pada sperma ikan lele sehingga mengakibatkan sperma ikan lele lemah dan tidak mendapat asupan energi yang cukup untuk proses pembuahan telur ikan, yang menyebabkan hampir $29 \%$ telur mati tidak terbuahi pada konsentrasi ini $\mathrm{pH}$ menunjukkan 7,0. sedangkan konsentrasi perlakuan $\mathrm{B}$ dengan pemberian madu0,70 $\mathrm{ml}$ yaitu tingkat kehidupannya sebesar 65,56 \% Konsentrasi perlakuan B 0,70 ml madu dengan menggunakan madu memberikan tingkat kehidupan terhadap telur hampir 65,56\%. 
Rasio penetasanperlakuan B yang $65,56 \%$ ini tidak terlalu banyak terhadap penetasan. Hal ini karena pemberian konsentrasi perlakuan B 0,70 $\mathrm{ml}$ madu terlalu sedikit, madu hanya memberikan tingkat kehidupan sedkit bagi sperma telur ikan lele dan terdapat $34 \%$ telur mati akibat tidak terbuahi oleh sperma.

Kosentrasi $0 \mathrm{ml}$ madu atau tanpa madu perlakuan $\mathrm{A}$, tanpa pemberian madu hanya memberikan tingkat kehidupan sedikit bagi telur lele, $39 \%$ telur mati tidak terbuahi oleh sperma. Menurut Rustidja (2000) apabila pada proses perkembangan sperma kita dapat mengurangi aktivitas sperma sehingga dapat menjaga kualitas sperma pada proses penyimpanan dalam kurun waktu lama. Sehingga proses pembuahan telur dapat terbuahi dengan keseluruhan atau keberhasilan penetasan pada telur. Pada perlakuan A dengan $0 \mathrm{ml}$ madu atau tanpa madu terdapat lama proses telur menetas yaitu selama 19 jam. Dibandingkan dengan perlakuan yang menggunakan madu yaitu perlakuan $\mathrm{B}$ (0,70 ml madu), $\mathrm{C}(0,75 \mathrm{ml}$ madu), $\mathrm{D}(0,80 \mathrm{ml}$ madu) telur menetas selama 17 jam. Dapat diartikan bahwa konsentrasi 0 madu atau tanpa madu terdapat lama proses penetasan telur diakibatkan tidak terdapat sumber energi yang baik dari dalam madu.

Hasil analisa sidik ragam menunjukan bahwa perendaman telur ikan lele dengan madu berpengaruh nyata terhadap penetasan telur ikan lele ( $\mathrm{F}$ hitung $4,92>$ dari $\mathrm{F}$ tabel taraf $5 \%=4,07$ ). Untuk mengetahui tingkat perbedaan dari masing-masing perlakuan dilakukan uji BNT ( beda nyata terkecil) (lampiran 3). Menurut Mar'ati (2007) bahwa pengobatan dengan cara memberikan pengencer pada sperma menggunakan bahan alami seperti halnya madu lebih efektif menyediakan zat makanan sebagai sumber energi, sebagai penyanggah $\mathrm{pH}$, mempertahankan tekanan osmotik dan keseimbangan elektrolit yang sesuai, serta mencegah pertumbuhan kuman, dengan konsentrasi madu 0,60 $\mathrm{ml}, 0,65 \mathrm{ml}, 0,70 \mathrm{ml}$ madu/ liter air.

Perendaman dengan menggunakan madu membuat $\mathrm{pH}$ menjadi stabil. Sifat anti jamur pada madu menunjukan kadar $\mathrm{pH}$ dibawah 7. Berdasarkan hasil penelitian $\mathrm{pH}$ stabil mempunyai pengaruh terhadap perkembangan embrio lebih cepat. Perendaman telur dengan madu yang sedikit menyebabkan semakin kurangnya suplai makanan masuk dalam telur sehingga embrio semakin kurang aktif bergerak dan akhirnya telur menjadi lambat menetas pada waktunya. Penetasan terjadi karena adanya kerja mekanik. Kerja mekanik terjadi karena embrio sering mengubah posisinya karena kekurangan ruang dalam cangkangnya, atau karena embrio lebih panjang dari lingkungan dalam cangkangnya.

Jamur akan menyerang telur ikan pada kondisi lingkungan yang tidak baik. Telur ikan tersebut akan terserang jamur yang ditandai dengan ditumbuhi benang-benang halus seperti kapas pada permukaan telur. Pada awalnya jamur ini tidak bebrbahaya tapi bila serangannya tidak dihentikan jamur akan menyebar pada telur yanga lain dan telur akan mati. Penanggulangan terhadap jamur yang baik untuk telur yaitu menggunakan 
perendaman dengan madu. Arie (2008) menyebutkan bahwa Saprolegnia sp merupakan salah satu jamur yang sering menyerang telur dan larva ikan air tawar. Jamur akan menyerang pada telur ikan pada kondisi yang tidak baik.

Hasil rata-rata daya telur ikan lele (Clarias sp) yang ditetaskan dalam penelitian ini menunjukan hasil yang baik pada perlakuan D yakni $76,67 \%$. Nilai rata-rata daya tetas $\mathrm{d}$ ari ikan lele (Clarias $\mathrm{sp}$ ) disajikan dalam Gambar 1

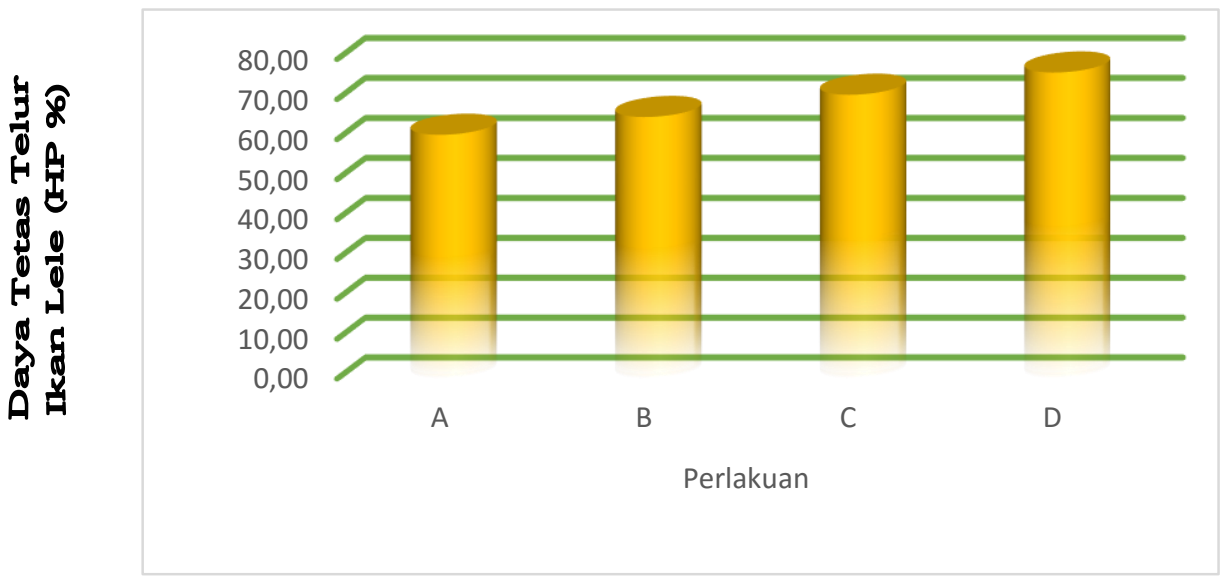

Gambar 1. Hatching Percentage Ikan Lele (Clarias sp)

Tabel 2. Uji ANOVA Satu Arah Rata-Rata Hatching Percentage Ikan Lele (Clarias sp)

Berdasarkan hasil uji Anova satu arah (Tabel 2) diketahui bahwa nilai $\mathrm{F}$ hitung= $4,92>\mathrm{F}_{\text {tabel }} 5 \%=4,07 \mathrm{~F}_{\text {tabel }}$ taraf $1 \%=7,59$ sehingga $\mathrm{H}_{1}$ diterima dan $\mathrm{H}_{0}$ ditolak,

\begin{tabular}{|l|r|r|r|r|r|r|r|}
\hline \multirow{2}{*}{$\begin{array}{c}\text { Sumber } \\
\text { Keragaman }\end{array}$} & DB & JK & KT & \multirow{2}{*}{ Fhitung } & \multicolumn{2}{|c|}{ Ftabel } & \multirow{2}{*}{ FK } \\
\cline { 1 - 5 } & & & & & $\mathbf{5 \%}$ & $\mathbf{1 \%}$ & \\
Perlakuan & 3 & 410.20 & 136.73 & $4.92 *$ & 4.07 & 7.59 & \multirow{2}{*}{56483.9} \\
\hline Galat & 8 & 222.14 & 27.77 & & & & \\
\hline Total & 11 & 632.34 & & & & & \\
\hline
\end{tabular}

signifikan pada $\mathrm{F}$ hitung lebih besar jumlahnya dari $\mathrm{F}$ table.

Untuk menguatkan hasil uji Anova satu arah maka dilakukan uji BNT (tabel 3) untuk melihat perlakuan mana saja yang memiliki perbedaan nyata terkecil $\left({ }^{*}\right)$ atau detail perbedaan secara rinci antar setiap perlakuan. Hasil uji BNT menunjukkan bahwa semua perlakuan terdapat tanda $\left({ }^{*}\right)$ yang berarti bahwa antar setiap perlakuan terdapat perbedaan, sehiggga keempat perlakuan menghasilkan Hatching Percentage (HP) dengan pemberian madu pada pengenceran sperma ikan lele (Clarias sp)dengan perlakuan yang berbeda. 
Tabel 3. Uji Beda Nyata Terkecil Rata-Rata Hatching Percentage Ikan Lele (Clarias sp)

\begin{tabular}{|c|c|c|}
\hline Perlakuan & Rataan & Notasi \\
\hline A & 61,11 & $\mathrm{a}^{*}$ \\
\hline B & 65,56 & $\mathrm{ab}^{*}$ \\
\hline C & 71,11 & $\mathrm{bc}^{*}$ \\
\hline D & 76,67 & $\mathrm{c}^{*}$ \\
\hline
\end{tabular}

Pengujian diketahui bahwa pada penelitian ini keempat perlakuan hasilnya berbeda nyata, sehingga hipotesis bahwa ada perbedaan diantara keempat perlakuan terhadap Hatching Presentase (HP) ikan lele (Clarias sp) terbukti. Dengan demikian dapat disimpulkan bahwa keempat perlakuan menghasilkan Hathing Presentase (HP), pemberian madu pada pengenceran sperma berpengaruh nyata terhadap daya tetas ikan lele (Clarias $\mathrm{sp}$ ).

\subsection{Parameter Kualitas Air}

Penetasan telur ikan lele (Clarias $\mathrm{sp}$ ) selain dipengaruhi oleh pemberian madu dapat dipengaruhi oleh kualitas air yang digunakan saat melakukan penetasan, kualitas air yang diamati dalam penelitian ini yakni, oksigen terlarut (DO), pH, suhu. Pengukuran kualitas air dalam penelitian. Untuk lebih jelas kualitas air dalam media penetasan setiap perlakuan disajikan dalam Tabel 4.

Tabel 4. Kualitas air dalam 4 perlakuan selama proses penelitian

\begin{tabular}{ccccc}
\hline $\begin{array}{c}\text { Kualitas } \\
\text { Air }\end{array}$ & A & B & C & D \\
\hline DO $(\mathrm{mg} / 1)$ & 3.9 & 4.1 & 3.9 & 3.8 \\
Suhu $\left({ }^{0} \mathrm{C}\right)$ & 27.88 & 27.17 & 28 & 24,5 \\
$\mathrm{pH}$ & 7 & 7 & 7 & 6,67 \\
\hline
\end{tabular}


Berdasarkan Tabel 4, penelitian ikan lele (Clarias sp) untuk parameter air memenuhi kualitas air yang dipakai untuk penetasan ikan lele (Clarias sp) proses penetasan suhu ${ }^{0} \mathrm{C}$ perlakuan $\mathrm{A}(27,88)$, perlakuan $\mathrm{B}(27,17)$, perlakuan C (28) dan perlakuan D $(24,5)$, Untuk $\mathrm{pH}$ pada perlaukuan A $(7)$, perlakuan B (7), perlakuan C (7), dan perlakuan D $(6,67)$, untuk DO perlakuan A $(3,9)$, B $(4,1)$, C $(3,9)$ dan perlakuan D (3.8) pada taraf penelitian inikualitas air baik oksigen terlarut (DO), $\mathrm{pH}$, dan Suhu masih dalam posisi stabil. Suhu yang baik untuk penetasan ikan lele (Clarias sp) berkisar antara 27-30 $\mathrm{C}$. Faktor lingkungan merupakan faktor yang mempengaruhi perkembangan sel telur sejak pembuahan sampai telur menetas antara lain suhu dan $\mathrm{pH}$.

Derajat keasaman $(\mathrm{pH})$ selama penelitian berkisar antara 6.67 kisaran ini masih berada pada kisaran yang cocok untuk penetasan ikan lele. Irianto (2007) menyatakan bahwa untuk kegiatan penetasan ikan lele yang baik harus mempunyai nilai $\mathrm{pH}$ dibawah 7,0, karena sifat asam akan mempengaruhi penetasan telur yang lebih cepat. Kandungan oksigen terlarut selama penelitian berkisar antara 3,8 ppm, kisaran ini masih berada dalam kisaran yang mendukung untuk kehidupan ikan. Murtidjo (2001) menjelaskan bahwa telur membutuhkan oksigen yang cukup, oksigen tersebut masuk kedalam telur secara difusi melaui lapisan permukaan cangkang telur, dalam penetasan telur oksigen dibutuhkan tetapi oksigen dikatakan sangat penting bagi pernafasan dan merupakan komponen utama (pembakaran dalam tubuh) yaitu metabolisme. Keperluan oksigen ikan tergantung pada jenis, umur dan aktifitasnya.

\subsection{Data Pendukung Madu Terhadap Penetasan Telur Ikan}

Daya tetas ikan mas pada semua perlakuan sperma tidak dapat membuahi sel telur yang telah disediakan. Dari 20 telur pada masing-masing perlakuan tidak terjadi pembuahaan oleh sperma diduga dikarenakan kondisi telur indukan yang belum matang. Hal ini dibuktikan pada sperma tanpa penyimpanan tetap saja tidak dapat membuahi sel telur setelah 24 jam, padahal tahap-tahap perkembangan telur menjadi larva ikan mas berlangsung selama 24-48 jam (Djarijah, et.al. 2001).

Menurut Rahardianto et al (2012), madu mengandung gula pereduksi sebanyak $67,84 \%$ yang terdiri dari fruktosa dan glukosa. Kandungan gula pereduksi ini digunakan oleh spermatozoa sebagai sumber energi dan juga madu mengandung mineral. Bahan utama yang dipakai spermatozoa sebagai sumber energi dari luar testis adalah fruktosa yang diubah menjadi asam laktat dan energi dengan bantuan enzim fruktolisin dalam proses glikolisis. menyatakan gula pereduksi tersebut dapat dimetabolisme oleh spermatozoa untuk menghasilkan energi berupa Adenosin Trifosfat atau ATP. Selanjutnya spermatozoa memanfaatkan ATP sebagai sumber energi dalam 
mempertahankan daya hidupnya, terdapat unsur elektrolit seperti $\mathrm{Na}, \mathrm{Ca}, \mathrm{K}$ berfungsi sebagai cryoprotectant di dalam pengencer.

\section{Kesimplan Dan Saran}

\subsection{Kesimpulan}

Berdasarkan hasil dan pembahasan, maka dapat disimpulkan bahwa pengenceran $0,80 \mathrm{ml}$ madu dengan $\mathrm{NaCl}$ Fisiologis $99.20 \mathrm{ml}$ memiliki hasil yang terbaik dibandingkan dengan pengenceran $0,75 \mathrm{ml}$ dan $0,70 \mathrm{ml}$ madu serta perlakuan tanpa madu. Pemberian madu pada ikan lele (Clarias sp) memberikan pengaruh yang nyata terhadap daya tetas telur. Hasil Hatching Percentage (HP) yang diperoleh pada perlakuan $\mathrm{A}=61,11 \%$, perlakuan $\mathrm{B}=$ $65,56 \%$, perlakuan $\mathrm{C}=71,11 \%$ dan perlakuan $\mathrm{D}=76,67 \%$. Hasil pengukuran kualitas air yakni suhu $24,5^{\circ} \mathrm{C}$, oksigen terlarut (DO) 3,8 ppm dan $\mathrm{pH}$ 6,67.

\subsection{Saran}

Perlu dilakukan penelitian dengan pemberian jenis madu yang berbeda dengan konsentrasi yang berbeda terhadap penetasan telur ikan lele (Clarias $\mathrm{sp}$ ), sebab pengguanaan madu dan dosis tertentu mengakibatkan sel telur ikan dapat terbuahi.

\section{Daftar Pustaka}

Arie, U. 2008. Pembenihan Dan Pembesaran Nila Gift. Penebar Swadaya, Jakarta.

Gusrina, 2008. Budidaya Ikan Untuk SMK. Diterbitkan oleh Direktorat Pembinaan Sekolah Menengah Kejuruan Departemen Pendidikan Nasional Tahun 2008.

Isnaini, N. dan Suyadi. 2000. Kualitas Semen Ayam Kedu Pada Suhu Kamar Dalam Pengencer Larutan $\mathrm{NaCl}$ Fisiologis dan Ringer's. J. Ternak Tropika. Vol. 1, No. 2.

Irianto, K. 2007. Mikrobiologi Umum. CV Yrama Widya. Bandung.

Katili, I. 2002. Studi Lama Waktu Penyimpanan Sperma Ikan Mas (Cyprinus carpio) Yang Telah Diencerkan Pada Suhu 4- $7{ }^{\circ} \mathrm{C}$ dan $28-30{ }^{\circ} \mathrm{C}$. Skripsi. Fakultas Perikanan dan Ilmu Kelautan. UNSRAT. Manado.

Mar'ati, K. 2007. Pengaruh Dosis Dan Lama Penyimpanan Pengencer Susu Skim Kuning Telurterhadap Kualitas Semen Ikan Mas (Cyprinus Carpio L.).Skripsi. Universitas Islam Negeri, Malang. 
Mahyuman, K. 2008. Panduan Lengkap Agrobisnis Lele. Penebar Swadaya. Jakarta. 171 hal.

Masrizal, Effrizal. 1997. Pengaruh Rasio Pengenceran Mani terhadap Fetilisasi Sperma dan Daya Tetas Telur Ikan Mas (Cyprinus carpio L). Fisheries J. Garing $6: 1-9$.

Muktiani, 2011. Budidaya Lele Sangkuriang dengan Kolam Terpal. Yogyakarta: Pustaka Baru Press.

Murtidjo, B., A. 2001. Beberapa Metode Pembenihan Ikan Air Tawar. Penerbit Kanisius, Yogyakarta.

Rahardhianto, A., Abdulgani, N., dan Trisyani, N. 2012. Pengaruh Konsentrasi Larutan Madu Dalam NaCl Fisiologis Terhadap Viabilitas dan Motilitas Spermatozoa Ikan Patin (Pangasius pangasius) Selama Masa Penyimpanan. Jurnal Sains dan Seni ITS Vol. 1 No. 1 (Sept. 2012) ISSN: 2301-928X.

Rustidja. 2000. Prospek Pembekuan Sperma. Universitas Brawijaya, Malang. 